\title{
News and views on meat: a brief introduction
}

\section{Stéphan Marette ${ }^{1}$}

Published online: 13 October 2020

(C) INRAE and Springer-Verlag France SAS, part of Springer Nature 2020

In recent years, meat consumption has been extensively examined in scientific studies, the media and/or non-governmental organisations. Numerous injunctions have gained momentum to question dietary habits that were previously perceived as normal and sustainable. Many public recommendations for consumers have emerged, advising a significant reduction in meat consumption. However, consumers face the major risk of being overwhelmed by both the complexity and the overlap of numerous issues related to human health, the environment and animal welfare. Additionally, meat producers face major difficulties to improve the sustainability of livestock raising and the quality of meat, which underlines the huge challenges involved in meat production.

Understanding the various consequences of meat consumption is an ongoing quest. The first edition of this "News and Views" section dealing with meat aims to shed new light on sensitive issues. The following three short articles provide original points of view that combine the fields of anthropology, philosophy and economics.

The first article, by Jocelyne Porcher, questions the meaning of "meat" for human beings made of flesh and blood. Because flesh is very close to meat, the reduction of the symbolic distance between humans and "other animals" directly challenges the future of meat consumption and opens up a new opportunity for alternative products, such as cultured meat produced by the in vitro cell replication of animal cells instead of meat from slaughterhouses.

The second article by Emmanuelle Lavaine, Philippe Majerus and Nicolas Treich focuses on livestock pollution via air pollution that was overlooked by previous costsbenefits analyses. These authors underline in particular the impact of this pollution on human health. This new problem raises the very sensitive issue of necessary regulations for capping air pollution in agriculture.

The third article by Pierre Dupraz complements the previous one and outlines the future challenges for the livestock sector to drastically reduce pollution. This final article suggests radical changes, from farmers to consumers, particularly with far higher taxes and subsidies than usually considered in previous academic papers. Knowing

Stéphan Marette

stephan.marette@agroparistech.fr

1 Université Paris-Saclay, INRAE, AgroParisTech, UMR Economie Publique, 78850 Grignon, France 
whether or not higher taxes and subsidies would be effectively implemented remains an open question.

These three articles should pave the way for debate to determine effective regulations. We hope you enjoy reading them before enjoying your next meal-with or without meat!

Publisher's note Springer Nature remains neutral with regard to jurisdictional claims in published maps and institutional affiliations. 